\title{
EFFECT OF MYCORRHIZAL SOIL AND GREEN MANURES ON GROWTH OF IPIL IPIL (LEUCAENA DIVERSIFOLIA L.)
}

\author{
Nabin Bhattarai*, Geeta Shrestha Vaidya* and Bikash Baral* \\ *Nepal Academy of Science and Technology.
}

\begin{abstract}
A pot trial research work of powder of Lantana camara L., Eupatorium adenophorum Spreng. and mycorrhizal soil on growth of Ipil Ipil (Leucaena diversifolia L.) fodder plant was conducted. Fifty gram of each green manure in powder form and mycorrhizal soil were used in each pot. Including control, altogether four treatments were made and each has fifty replicates. The treatment with green manure from Lantana camara showed maximum growth, survival and germination of the plants with maximum average length of $21.25 \mathrm{~cm}$ and $37.96 \mathrm{~cm}$ respectively, followed by Eupatorium adenophorum (16.51 cm and $23.46 \mathrm{~cm}$ ) which was statistically significant $(\mathrm{P}<0.05)$. Survival of plants was higher Lantana camara. Number of mycorrhizal spores, soil bulk density and water holding capacity was higher in Lantana treated soil followed by Eupatorium adenophorum, Mycorrhizal soil and control. The nutrient status of the soil improved than the eroded soil. The soil sample treated with Eupatorium adenophorum showed the maximum percentage of organic matter, potash, phosphorus and nitrogen content i.e. 1.95, 58.14, 13.65, 0.17, respectively followed by Lantana, mycorrhiza and control. The green manures prepared from these plants and mycorrhizal soil can be used for the growth of plants which improves the nutrient status of soil and increases the mycorrhizal biomass stabilizing the eroded and land slided area.
\end{abstract}

Key-words: Eupatorium adenophorum; Lantana camara growth; Microorganisms.

\section{INTRODUCTION}

Green manures, often known as cover crops, are grown to improve the structure and nutrient content of soil. They are used to protect the soil from erosion and also for control of weeds and diseases, especially soil born diseases and nematodes. They are cheap alternative to artificial fertilizers and can be used to complement animal manures. Generally herbaceous plants such as lupins, clover, vetch, treefoil, mustard and ryegrass are used as green manure. Leguminous green manure is more effective than other non-legume. They may also survive better and grow faster, and may be able to tolerate extreme weather conditions or poor soils. Use of green manure together with adequate residue management and crop rotation could be useful to conserve or increase soil fertility, promote nutrient cycling at farm scale and reduce the external inputs (Drinkwater et al. 1998; Melero et al. 2006).

Mycorrhiza a kind of fungus and symbiotic to roots of plants, increases the nutrient absorption efficiency of roots with the help of their hyphae. It has been estimated that at least $80 \%$ to $90 \%$ of the world's higher plants form mycorrhizae except few members belonging to cruciferae, cyperaceae, chenopodiaceae, junaceae and proteaceae (Smith \& Read, 1997). Aggregate stability is a way to estimate the ability of a soil to maintain good water infiltration rates, good tilth and adequate aeration for plant growth (Emerson et al. 1986, Kemper \& Rosenau, 1986). Their aggregate hyphae bind the soil particles and reduce the soil erosion. Some types of mycorrhiza produce a substance called glomalin which is important for binding the soil particles and stabilize the soil. They take up nutrients ( $\mathrm{N}$ and $\mathrm{P}$ ) in exchange for carbohydrates provided by the plant. They are classified according to the species.

Eupatorium adenophorum and Lantana camara are exotic and invasive plants to Nepal. They highly compete and disturb the growth of other plants. Ipil ipil (Leucaena diversifolia L.) is good fodder plant growing in a hilly region of Nepal.

The objective of the present research work was to determine the efficacy of mycorrhizal soil and green manures on growth of ipil ipil plant.

\section{MATERIALS AND METHODS}

The soil that is free or least containing microorganisms and mineral nutrients were collected from the Bisnkhu Narayan, Godawari and Kathmandu. Sampling of the mycorrhizal soil was done from the rhizospheric soil of the plant growing in Chalnakhel, Kathmandu. Fresh leaves and soft stems of E. adenophorum and L. camara were collected from Chobhar, Kathmandu. Fresh ipil ipil seeds were collected from the Fodder Department, NARC and were sown in the pots.

Collected soil was filled in pots. At first few numbers of pebbles were placed in bottom for good aeration. The collected plants were shade dried. After drying, these plants

Author for Correspondence: Nabin Bhattarai, Nepal Academy of Science and Technology, GPO Box 3323 Kathmandu. 
were ground to powder. Each treatment and control had fifty. Fifty gram of mycorrhizal soil and fifty gram of green manures were applied in the respected treatments. Soaked seeds treated with $1 \%$ Hydrogen Peroxide solution was sown on each pot and watered at every 15 days interval till the final observation. At six months and twelve months, the length of each plant was measured from respective treatments and data were analyzed with the help of SPSS program. Soil bulk density was determined with the help of soil core. Cores were injected into the soil of respected treatment's pots and picked out with full volume of soil and were weighed and were further heated over night at $105^{\circ} \mathrm{C}$ in hot air oven. After heating, final weights of the soils were taken.

Bulk Density of the soil was calculated by following equation:

$$
\begin{gathered}
\text { SBD = } \quad \begin{array}{c}
\text { Wt. of Oven Dried Soil Taken from Core } \\
\text { Volume of Core }
\end{array} \\
\begin{array}{c}
\text { Volume of Core }=\pi \mathrm{r}^{2} \mathrm{~h} \text { or } \frac{\pi \mathrm{d}^{2} \mathrm{~h}}{4} \\
\text { Where, } \\
\quad \pi=\frac{22}{7} \\
\mathrm{r}=\text { radius of core, } \mathrm{cm} \\
\mathrm{h}=\text { height of core, } \mathrm{cm}
\end{array}
\end{gathered}
$$

The soil texture was measured with the help of Soil Hygrometer. Fifty gram of soil was taken from each pot and poured into jar containing 1-L water. Ten ml of 20\% Sodium hexa metaphosphate solution was added and left for $24 \mathrm{~h}$ after which the jar was inverted, and the hygrometer was dipped till 40 seconds and the reading was noted. These solutions were left untouched for $2.5 \mathrm{~h}$, and finally the hygrometer was again dipped and the reading was taken. The process was repeated for three times, and their average values were calculated. These values corresponded with the figure of soil texture.

Mycorrhizal spores were analyzed by following wet sieving and decantation method adapted by Gerdemann and Nicolson (1963). Fifty gram of soil samples were taken from each pot for spore analysis.

Water holding capacity was performed with the aid of keen box bearing pores on lower surface. Different soil samples were taken from different pots with the help of $2 \mathrm{~mm}$ pore sized sieve and the soil uniformity was done and was placed in keen box and sunk into water over night. The moist weight of soil was taken and heated over night at $105^{\circ} \mathrm{C}$ in hot air oven and dry weight was taken. The following equation is used to calculate the percentage of moisture content of the soil.

Moisture content $(\%)=\frac{\text { Moist } / \text { Fresh weight }- \text { Dry weight }}{\text { Dry weight }} \times 100$

After one year different parameters of soil such as $\mathrm{pH}$ of soil was measured by electrode, organic matter by WalkleyBlack wet oxidation method (Walkley \& Black, 1934), available potash by Flame Photometer method, available phosphorus by modified Olsen's method and total nitrogen content by modified Kjeldahl method (Bremner \& Mulvaney, 1982).

\section{RESULTS AND DISCUSSION}

Plants height was measured at six and twelve months. Those treated with green manure of $L$. camara showed the maximum growth of ipil ipil plants. At the time of six and twelve months, the plants treated with Lantana showed higher average length statistically significant $(\mathrm{P}<0.05)$ i.e. $21.25 \mathrm{~cm}$ and $37.96 \mathrm{~cm}$ followed by E. adenophorum, mycorrhiza and control. The control showed the least average length of plants which proved that the eroded soil contains less amount of nutrients. The plant $L$. camara contains high amount of plant nutrients creating the favorable environment for the better plant development. The treatment inocula with L. camara showed the higher number of mycorrhizal spores, soil bulk density and water holding capacity, followed by $E$. adenophorum, mycorrhizal soil and control (Table 1).

The $L$. camara treatment showed maximum survival and maximum germination of ipil ipil plants followed by $E$. adenophorum, mycorrhiza and control. Those plants on control showed least survival and least germination of plants (Table 1, Fig 1).

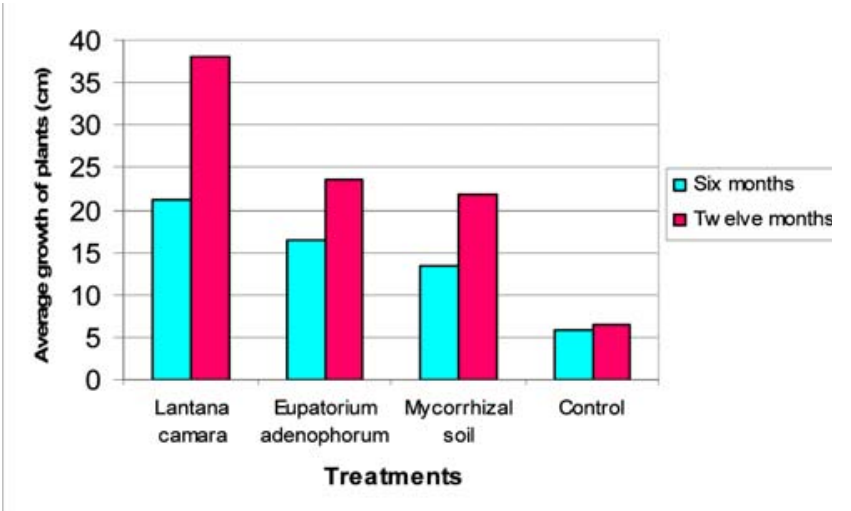

Fig. 1: Showed the average growth of Ipil Ipil plants within six and twelve months on different treatments.

The L camara treatment showed maximum growth and more survival of ipil ipil plants followed by Eupatorium adenophorum, mycorrhizae and control which was also statistically significant $(\mathrm{P}<0.05)$. The findings of this work was analogous to the work of Vaidya et al. (2008) and found that addition of organic matter on AM fungi could be an important contribution to plant survival in plantation on soils of eroded sides. This work is also similar to the work of Amaya-Carpio et al. (2009) and found that AMF and organic fertilizer inoculated plants showed higher growth, higher leaf elemental content and photosynthesis than the noninoculated plants. Those plants treated with mycorrhizae showed more growth and survival number than the control which is similar to the work of Menge et al. (1980) and reported that the increased growth of Avocado seedlings by 49-254\% 
Table 1: Growth, germination and survival rate of ipil ipil plants.

\begin{tabular}{|c|c|c|c|c|c|c|c|c|c|}
\hline \multirow[t]{2}{*}{ Treatments } & \multirow[t]{2}{*}{ Types of manure } & \multirow{2}{*}{$\begin{array}{c}\text { Wt. of } \\
\text { manures } \\
\text { (g) }\end{array}$} & \multicolumn{2}{|c|}{ Average height cm* } & \multicolumn{5}{|c|}{ No. of Plants* } \\
\hline & & & 6 months & 12 months & $\begin{array}{l}\text { Germinated } \\
\text { seedings }\end{array}$ & $\begin{array}{l}\text { Germ }^{\mathrm{n}} \\
\%\end{array}$ & Dead & Survival & $\begin{array}{c}\text { survival } \\
\% \\
\end{array}$ \\
\hline T1 & Lantana Powder & 50.00 & 21.25 & 37.96 & 48.00 & 96 & 1.00 & 47.00 & 97.91 \\
\hline $\mathbf{T} 2$ & EupatoriummPowder & 50.00 & 16.51 & 23.46 & 45.00 & 90 & 2.00 & 43.00 & 95.55 \\
\hline T3 & Mycorrhizal soil & 50.00 & 13.40 & 21.77 & 41.00 & 82 & 4.00 & 37.00 & 90.24 \\
\hline T4 & Control & 0.00 & 5.84 & 6.38 & 26.00 & 52 & 10.00 & 16.00 & 61.53 \\
\hline
\end{tabular}

*Mean of 50 replications.

Table 2: Production of mycorrhizal spores, water holding capacity and bulk density of different treatments.

\begin{tabular}{|c|c|c|c|c|c|}
\hline Treatments & $\begin{array}{l}\text { Types of } \\
\text { manure } \\
\text { Used }\end{array}$ & $\begin{array}{c}\text { Wt. of soil } \\
\text { Taken from } \\
\text { Each replicate } \\
\text { (gm) }\end{array}$ & $\begin{array}{l}\text { Number of } \\
\text { mycorrhizal } \\
\text { spores }\end{array}$ & $\begin{array}{c}\text { Bulk } \\
\text { Density (gm/ } \\
\left.\mathbf{c m}^{3}\right)\end{array}$ & $\begin{array}{c}\text { Percentage } \\
\text { of water } \\
\text { holding } \\
\text { capacity } \\
\end{array}$ \\
\hline T1 & L. camara & 50.00 & 70.4 & 1.32 & 32.85 \\
\hline $\mathbf{T} 2$ & E. adenophorum & 50.00 & 61.6 & 1.32 & 31.83 \\
\hline T3 & Mycorrhizal soil & 50.00 & 45.0 & 1.26 & 28.86 \\
\hline T4 & Control & 50.00 & 3.5 & 1.18 & 26.60 \\
\hline
\end{tabular}

Table 3: Nutrient content of the soil of different treatments.

\begin{tabular}{llccccc}
\hline Treatments & Types of manure used & $\mathbf{P}^{\mathrm{H}}$ & $\begin{array}{c}\text { Organic } \\
\text { matter } \\
\text { content (\%) }\end{array}$ & $\begin{array}{c}\text { Available } \\
\text { potash (K) } \\
\text { content (kg/h) }\end{array}$ & $\begin{array}{c}\text { Available } \\
\text { phosphorus (P) } \\
\text { content (kg/h) }\end{array} \begin{array}{c}\text { Total } \\
\text { nitrogen } \\
\mathbf{( N )} \mathbf{c o n t e n t} \\
\mathbf{( \% )}\end{array}$ \\
\hline T1 & L. camara Powder & 8.19 & 1.67 & 38.76 & 11.5 & 0.153 \\
T2 & E. adenophorum Powder & 8.17 & 1.95 & 58.14 & 13.65 & 0.175 \\
T3 & Mycorrhizal soil & 8.26 & 1.12 & 38.76 & 13.18 & 0.063 \\
T4 & Control & 8.4 & 0.98 & 38.76 & 2.24 & 0.042 \\
Eroded soil & ------ & 8.6 & 0.92 & 1.0 & 0.3 & 0.02 \\
\hline
\end{tabular}

in increased loamy sand by inoculation with two isolates of Glomus faciculatum. The present work also gets support by the works of Dag et al. (2009) and Zhou et al. (2009) and found that mycorrhizae inoculated trees showed increase in height, root and shoot biomass than non- inoculated plants.

The soil treated with $L$. camara showed the maximum average number of growth of mycorrhizal spores, water holding capacity and bulk density, followed by $E$. adenophorum, mycorrhizal and control (Table 2). The soil treated with $L$. camara and E. adenophorum showed the higher number of mycorrhizal spores which is analogous to the work of Vaidya et al. (2008) and found that organic matter addition enhanced the production of AM fungal and bacterial biomass. The addition of organic matter i.e. green manures created the suitable environment for production of mycorrhizal spores. The results of the present work is supported by the result of Zarea et al. (2008) and found that rotation of clover species and mycorrhiza increased the colonization and mycorrhizal biomass. Except control, all treatments showed the higher bulk density, nutrient content and water holding capacity. It means that there was higher production of mycorrhizal spores that bound soil particles and increased the compactness of soil with the increment in the soil nutrient contents.

The breakdown of organic matter by microorganisms, compounds are formed that are resistant to decomposition such as gums, waxes, and resins. These compounds and the mycelia, mucus and slime produced by the microorganisms 
help bind together soil particles as granules or aggregates (Ternan et al. 1996). A well-aggregated soil tills easily, and has a high water infiltration rate. Increased level of organic matter also influence soil humus, providing a wide range of benefits to crop production. The result of the present work coincides with the work of the Condor et al. (2007) and found that application of the effective microorganism and green manure increased soil aggregation, reduce compaction, increase soil porosity, water infiltration and rooting depth.

Before treatment, the nutrient status of the soil was lower. After the completion of work, the nutrient status of the soil was improved with the decrease of the $\mathrm{pH}$ value. The soil sample treated with E. adenophorum showed the higher percentage of organic matter, potash, phosphorus and nitrogen content i.e.1.95, 58.14, 13.65, 0.175\% respectively, followed by L. camara, mycorrhizal soil and control (Table 3). The soil from the control improved the nutrient status than the eroded soil which was used for the present work but showed the least percentage of organic matter, potash, phosphorus and nitrogen content in comparison to the other treatments. Major benefit obtained from green manures was the addition of organic matter to the soil and increased soil microorganisms. The soil microbes multiply and attack the freshly incorporated plant material. During microbial breakdown, nutrients held within the plant tissues are released and are made available to the plants or crop. The findings of the preset work also coincides with the work of Zarea et al., (2008) who found that green manures of two clover species, mycorrhiza rotation significantly increased the phosphorus availability, total nitrogen content, microbial biomass, soil organic carbon and nitrogen fixing Rhizobia. During decomposition of organic matter, carbonic and other organic acids were formed as a byproduct of microbial activity. These organic acids react with insoluble mineral rocks and phosphate precipitates, releasing phosphates and exchangeable nutrients.

\section{CONCLUSION}

It is concluded that dry powder of $L$. camara and $E$. adenophorum, and mycorrhizae enhanced the growth of plants, improved the nutrient status of soil with the final increment in the mycorrhizal spores. These plants and mycorrhizae can be used for the betterment of the crops as well as other plants, stabilize the eroded soil and increase the nutrient pool of the soil. Higher the organic matter in the soil, higher will be its carbon storage properties.

\section{ACKNOWLEDGEMENT}

The authors are thankful to NAST for providing research facilities. We owe our sincere thanks to HICAST for nutrient analysis of the soil. We would also like to thank Pragun Shrestha, NARC for helping us to find the bulk density and water holding capacity of the soil.

\section{REFERENCES}

Amaya-Carpio, L., F.T. Fox Davies, C.T. He. 2009. Arbuscular mycorrhizal fungi and organic fertilizer influence photosynthesis, root phosphate activity, nutrition and groeth of Ipomea carnea sp fistulosa. Photosynthetica, 47 (1): 1-10.
Bremner, J.M. and C.S. Mulvaney. 1982. Nitrogen-total, In: Methods of Soil Analysis, Part 2 Chemical and Microbiological Properties (Ed.A.L. Page), SSSA Book series No: 9, Madison, pp,595-622.

Condor Golec, Anibal F., P. Gonzalez Perez., C. Lokare. 2007. Effect of microorganism and green manure on the soil productivity in Brazil, Rev. Peru. Biol., 14(2): 315-319.

Cooke, R. 1977. The Biology of Symbiotic Fungi, John Wiley and Sons, Chichester, New York, pp, 185-259.

Dag, A., U. Yermiyahu., A. Ben-Gal., I. Zipori., Y. Kapulnik. 2009. Nursery and post transplant field response of olive trees to arbuscular mycorrhizal fungi in an arid region, Crop and Pasture Science, 60(5): 427-433.

Drinkwater, L.E., Wagoner, P. and M. Sarrantonio. 1998. Legumebased cropping systems have reduced carbon and nitrogen losses. Nature, 396: 262-265.

Emerson, W.W., R.C. Foster and J.M. Oades. 1986. Organomineral complexes in relation to soil aggregation and structure. In: Interactions of Soil Minerals with Natural Organics and Microbes. Soil Science Society of America, Madison, WI, USA, 17: 521-548.

Gerdemann, J.W. and T.H. Nicolson. 1963. Spores of mycorrhizal endogone species extract from soil by wet sieving and decanting, Transactions of the British Mycological Society, 46: 235 - 244.

Kemper, W.D. and R.C. Rosenau. 1986. Aggregate stability and size distribution. In: Methods of soil analysis, Part 1. Physical and mineralogical methods. Agronomy monograph 2nd edn. American society of agronomy, Madison, WI, USA, 9: 425-444.

Mäder P., A. Fliebach., D. Dubois., L. Gunst and P. Fried. 2002. Soil Fertility and biodiversity in Organic Farming. Science, 296: 1694169.

Melero S., J. C. Riuz Porrai., J.F. Herencia and E. Madejon. 2006. Chemical and biochemical properties in a sylty loam soil under conventional and organic management. Soil and Tillage Research, 90: $162-170$.

Menge, J.A., J.La. Rue., C.K. Labanauskas and E.L.V. Johnson. 1980. The Effect of two mycorrhizal fungi upon growth and nutrition of Avocado seedlings grown with six fertilizer treatments, J. Am. Soc. Hortic. Sci., 18:191-196.

Smith, R.J. and Jr.W. Klomparens. 1980. Biological Control News and Information, 1: 291-294.

Smith, S.E. and D.J. Read. 1997. Mycorrhizal symbiosis, 2-nd edn, Academic Press, Sandiago, P-605.

Subba Rao, N.S. 1982. Biofertilizers. In: Advances in Agricultural Microbiology, Oxford and IBH Pub, Com., New Delhi, pp 219-242.

Ternan, J.L., A.G. Williams., A. Elmes., R. Hartley. 1996. Aggregate stability of soils in central Spain and the role of land management. Earth Surf. Processes Landf, 21: 181-193.

Vaidya G.S., K. Shrestha, B.R. Khadge., N.C. Johnson and H. Wallander. 2008. Organic matter stimulates bacteria and arbuscular mycorrhizal fungi in Bauhinia purpurea and Leucaena diversifolia plantation on eroded slopes in Nepal, Restoration Ecology, 16(1): 79-87.

Walkley, A. and A. I. Black. 1934. An examination of the Degtjareff method for determining soil organic matter and proposed modification of the chromic acid titration method. Soil Science. 37: 29-38.

Zarea, M.J., Ghalavand, A., Mohamadi Goltapeh, E., Rejali, F. and Z. T. Ghamsari. 2008. Green manures, mycorrhizas and soil fertility, American- Eurasian Journal of Sustainable Agriculture, 2(3): 284-299.

Zhou Z., L. Chen., X. Huang. 2009. Screening of Chinese tulip tree mycorrhizal fungi and effect of growing seedling with mycorrhizae. Forest Research. 22(2):196-199. 